\title{
The Prospects of Russia and India Jointly Leading a New Non-Aligned Movement
}

\author{
A. Korybko, V.M. Morozov \\ Moscow State Institute of International Relations (university) of the Ministry of Foreign Affairs of Russia
}

The ongoing global systemic transition is transforming international relations from its erstwhile unipolarity to what experts agree is either multipolarity or, less popularly, bipolarity. However one chooses to describe the present world order, it's clear that the US and China are the main global players, which places Russia and India - decades-long strategic partners - in a junior position vis-a-vis both of them, especially their mutual Chinese neighbor with whom they share membership in BRICS and the SCO. The neorealist school of International Relations Theory preaches the need to pursue national interests, which sometimes align with others', and it is argued in the article that it is with this idea in mind that both countries have a motivation to jointly improve their strategic positions relative to the People's Republic, albeit in a non-hostile manner that avoids the risk of inadvertently triggering a security dilemma and reversing the recent gains made in Eurasian integration.

Two articles published by Russia's Valdai Club in 2019 indicated the possibility of creating a new Non-Aligned Movement, with the most recent one proposing that it be jointly led by Russia and India in order to advance the aforementioned neo-realist objective of balancing China. This suggestion is very intriguing and deserves some further elaboration, to which end the present research was conducted in order to place the new Non-Aligned Movement proposal in a strategic context relevant to the ongoing global systemic transition. Nearly a dozen articles and reports by Russian experts were analyzed, resulting in the conclusion that the proposal is a promising one but requires much more research into its challenges and opportunities in order to become more than just a proposed concept. In the event that any tangible progress is made on it, however, it must be done so extremely carefully in order for China not to misunderstand its intentions.

Key words: Russia, India, China, multipolarity, bipolarity, New Non-Aligned Movement, Peaceful Development Movement, South Asia, Eurasia 
ussia has closer and more strategic relations with India than it does with practically any other country apart from China outside of the post-Soviet space, Cold War, the subsequent one of unipolarity that followed, or the ongoing global systemic transition to what is popularly regarded by many to be multipolarity. RussianIndian ties have remained strong, though they have nevertheless been tested at times. The present moment is a defining one for both countries because it affords them the opportunity to strengthen their relations by transitioning them from their hitherto dependence on mostly weapons- and energy-related trade into other spheres of prioritized cooperation such as the commercial one that would contribute to making their strategic partnership a more influential international force.

One of the main questions of contemporary international relations is whether the current world order is already truly multipolar or if it's really in an unofficial state of bipolarity between the existing US hegemon and its rising Chinese competitor. This question is more than just of academic interest since the answer will shape the strategic contours of Russian-Indian relations, especially in the event that both countries tacitly agree that contemporary international relations are more bipolar than multipolar. The resultant policymaking outcome would naturally be to pool their efforts into jointly creating a third pole of influence that could more adroitly balance between the other two and therefore accelerate the multipolar transition over time. Moreover, this development could also attract the attention of less powerful states that might gravitate towards the third pole.

Russia and India might believe that it is in their best interests to pioneer a new Non-Aligned Movement (Neo-NAM), the latest version of this idea was proposed by a Valdai Club program director Oleg Barabanov in May 2019 and expanded upon in detail by his two colleagues, Alexey Kupriyanov and Alexander Korolev, several months later in September 2019 following Indian Prime Minister Modi's milestone participation in the Eastern Economic Forum (EEF) as President Putin's guest of honor. The latter two experts proposed that the two countries jointly lead the new network, which they called the "Peaceful Development Movement" (PDM). This idea is certainly intriguing, but in order to better understand its possible game-changing role, it must be placed into the proper strategic context.

It is important to say a few words about the original Non-Aligned Movement (NAM) and the initial academic discussion of a new version of it that the authors were able to discover. NAM was first conceptualized during the Bandung Conference in 1955 as a platform for the dozens of countries caught between the two superpowers of the time to collectively balance between them. It was formally established in Belgrade in 1961, and Egypt, India, Indonesia, and Yugoslavia were its leading members. This organization was most active and symbolic during the Cold War but became somewhat obscure after 1991 (Ray 2012). Marco A. Vieira from the University of Birmingham, however, argues that it still continued to provide its members with what he regards as ontological security (Vieira 2016). Citing scholar Anthony Giddens, Vieira describes 
this concept as helping actors counter "'ontological anxiety'...by developing and maintaining a coherent understanding of the world and a stable sense of their presence in it", which is important because they "are fundamentally driven by a psychological desire for predictability and self-understanding, which shapes expectations and dispositions toward other actors." He also references Jef Huysmans, who "first applied the term ontological security to the field of critical security studies", after which the scholarship "primarily split into two distinct theoretical and analytical treatments of the term: (1) the sociological or exogenous approach and (2) the psychological or endogenous approach." In summary, Vieira believes that the NAM allowed its members to experience a 'shared self-identity', which the authors of the present article consider being relevant for the relations between Russia and India (endogenous approach) and between themselves and others (exogenous approach).

This 'shared self-identity' is changing in parallel with the contemporary international system, and rather than reflecting a middle ground between the US and USSR or opposing American unilateralism, it signifies balancing between the US and China. The evolving role of the NAM explains the reason for considering the prospects for a “'new' non-alignment", as Professor Abdul Nafey of the Jawaharlal Nehru University first postulated in his article (Nafey 2005). Although referring at the time to the IBSA (India, Brazil, and South Africa) Forum, the logic behind his proposal is pertinent in the current context and to the present article. Nafey believes that the NAM was "too large and amorphous" to successfully protect the multilateral rules-based order, and that changes in the international system during the 1980s greatly weakened its unity and overall effectiveness. For this reason, he proposes that India, Brazil, and South Africa do more to comprehensively enhance their cooperation with one another in order to overcome these shortcomings and ultimately revive the spirit of NAM.

We consider Russia and India capable to function as dual cores of the Neo-NAM because they both fulfill Nafey's requirements of potential great powers in that they have "power resources, geopolitical attributes, and attitudes and goals in international system" and expand their capabilities, which is another crucial indicator of a potential great power according to Nafey. The Indian scholar's views that the NAM was weakened by the gradual global economic restructuring of the 1980s and the briefly intensified Cold War between the superpowers is relevant today in the sense that the world is once again undergoing an economic restructuring between the competing models of economic nationalism spearheaded by the US and the reformed globalization vision advanced by China's Belt \& Road Initiative (BRI). Remembering the need for the NAM countries to remain focused during such transformative times (which according to him wasn't the case during the crucial decade of the 1980s), our argument is that Russia and India can jointly take up the mantle of leadership of the Neo-NAM in a manner which overcomes the structural challenges of the past and therefore helps revive its relevance.

Therein lays the significance of the present research, which references a few official documents and then examines the views of leading Russian experts on the state and 
potential of bilateral relations between Russia and India. The objective is to discern the stance of influential figures who might in the future have an impact on shaping policy by virtue of their prestigious professional positions and attendant institutional contacts, to which end their published works will be analyzed. Once the strategic backdrop has been established, the research will then proceed to discussing the two previously mentioned works about the Neo-NAM, with a focus on the one authored by Kupriyanov and Korolev. After that, a review of the joint statement issued by President Putin and Prime Minister Modi after the EEF will be undertaken in order to show the synergy between their governments' official vision and the Valdai Club's, which were released around the same time. After it, the article discusses challenges and opportunities inherent to the Neo-NAM, after which a review of the study's results will be given prior to a few concluding remarks about the proposal's overall viability.

\section{The Present State of Russian-Indian Relations}

The Russian-Indian partnership has the grand strategic relevance in modern-day geopolitics of lessening Russia's dependence on China after the country enacted its so-called "Turn to the East" following the West's anti-Russian sanctions in 2014 (Kaushiki, Hilal 2015). Relations with India have rapidly progressed to the point since then where Russia has invited its South Asian partner to participate in economic projects in the Arctic and the Russian Far East, mostly concerning the resource extraction industry, but perhaps one day they might even take a military dimension if the two clinch a military logistics deal like they've been reportedly discussing throughout $2019^{1}$. Even in its purely economic sense, this is still very symbolic because Russia is able to demonstrate to China that it has other strategic Asian partners, which sends the message that Moscow is not desperate to agree to any deal - whether economic or otherwise with Beijing unless the terms are fair. In addition, inviting India to expand its presence in the Arctic and the Far East shows that Russia is serving as a gateway for its partner to enter new geographic domains, all with a view towards India reciprocating in other regions such as ASEAN, South Asia, and Africa. This could realistically take the form of trilateral partnerships with whatever the third party may be and could help Russia expand its economic influence in new markets, which is very important given the ongoing sanctions regime against it.

Prime Minister Modi's participation in the 2019 EEF was extremely significant because it saw him and President Putin agree to establish what has been described as the Vladivostok-Chennai Maritime Corridor (VCMC) $)^{2}$. Its envisaged function is

\footnotetext{
1 Gurung S.K. Rajnath Singh Heads to Russia, to Discuss Defence Logistics Pact. The Economic Times. 5 Nov. 2019. URL: https://economictimes.indiatimes.com/news/defence/rajnath-singh-heads-to-russia-to-discuss-defence-logistics-pact/ articleshow/71915888.cms?from $=$ mdr (accessed 20.03.2020)

2 India, Russia Sign Pact to Open Maritime Route between Chennai and Vladivostok. News18.4 Sept. 2019. URL:https://www. news18.com/news/india/india-russia-sign-pact-to-open-maritime-route-between-chennai-and-vladivostok-2297059. html (accessed 20.03.2020)
} 
to facilitate Russian resource exports to India but it could also diversify and promote commercial activity as well. In addition, the VCMC might even be leveraged one day to lay the groundwork for Russia's future participation in the Indo-Japanese "AsiaAfrica Growth Corridor"3 (AAGC). If taken to this extent, Russia could eventually clinch more economic deals. In fact, mutually beneficial Russian-Indian cooperation in third-party states and networks could also prove the viability of the Neo-NAM concept, which could be aimed to create a third pole of power in what some experts consider to be the present bipolar world. These concepts will be returned to later in the research but are being introduced now in order to frame the subsequent analysis for the reader in a way that enables them to understand the larger significance of RussianIndian relations.

The strategic ties between these two countries were formalized through the "Declaration on Strategic Partnership Between the Republic of India and the Russian Federation" that was promulgated in 2000. Its first paragraphs state that the document is founded upon the 1971 Treaty of Peace, Friendship and Cooperation ${ }^{4}$ that eventually led to the 1993 Treaty of Friendship and Cooperation and the 1994 Declaration on the Further Development and Intensification of Cooperation after the USSR dissolved in 1991. According to the article "India and Russia: New Prospects for Strategic Partnership in the $21^{\text {st }}$ Century" that President Putin wrote before his visit to India in December 2012, Russian-Indian relations are extremely promising and can have a positive impact on international relations. The Russian leader suggested that the two countries cooperate more closely in multilateral institutions like BRICS (Lumumba-Kasongo 2015) and in the spheres of military-technical ties, people-to-people relations, and nuclear energy. Several years later, these proposals formed the basis of the report by the Russian International Affairs Council (RIAC) titled "100 Postulates on Russia-India Relations", which was jointly published by Oleg Popadyuk and Igor Denisov in September 2016.

\section{Expert Assessments on Russian-Indian Relations}

The experts acknowledge that Russia and India support multipolarity, but "the prospects of their development depend on the nature of Russia and India's interactions with other global players, in particular, with the United States and China"'. Popady-

\footnotetext{
3 Prakash A. The Asia - Africa Growth Corridor: Bringing Together Old Partnerships and New Initiatives. Observer Research Foundation. 25 Apr. 2018. URL: https://www.orfonline.org/research/the-asia-africa-growth-corridor-bringing-togetherold- partnerships-and-new-initiatives/ (accessed 20.03.2020

4 Treaty of Peace, Friendship and Cooperation between the Government of India and the Government of the Union of Soviet Socialist Republics. Ministry of External Affairs, Government of India, 9 Aug. 1971. URL: https://mea.gov.in/bilateraldocuments.htm?dtl/5139/Treaty+of+ (accessed 20.03.2020)

5 Putin V. India and Russia: New Prospects for Strategic Partnership in the 21st Century. Official Internet Resources of the President of Russia. 23 Dec. 2012. URL: http://en.kremlin.ru/events/president/news/17180 (accessed 20.03.2020))

6 Popadyuk O., Denisov I. 2016. 100 Postulates on Russia-India Relations. Russian International Affairs Council. 5 Sept. URL: https://russiancouncil.ru/en/activity/workingpapers/100-tezisov-o-rossiysko-indiyskikh-otnosheniyakh/ (accessed 20.03.2020)

7 Ibid.
} 
uk and Denisov suggested that Russia invest in India's "Make in India" program and predicted that the North-South Transport Corridor (NSTC) could further improve their commercial ties. They also suggested that the Eurasian Economic Union (EAEU) (Entina 2014) sign a free trade deal with India. Something real interesting that they wrote is that Russia should "[involve] India in settling violent conflicts around the world, solving pressing political issues, and reforming the international financial and economic architecture", which confirms the observation written earlier about Russia serving as a gateway for India's expansion of influence into new domains. The authors of the present article believe that this could be done to balance China, something that Popadyuk and Denisov hint at too. They wrote that "many Asian countries listen to New Delhi, particularly those that are wary of China's strengthening positions on the global stage". This is one of the motivations behind the proposed Neo-NAM that will be discussed later.

A member of the Government Expert Council Yaroslav Lissovolik wrote at the same time about "The Crossroads of Eurasia and Asia Pacific" tion to "three key trajectories" of Eurasian-Pacific integration, which he identified as Northeast Asia, East Asia, and Southeast Asia, which could be advanced through the Russian Far East, South Korea and Japan, and ASEAN, correspondingly. According to him, "the advancement towards establishing and reinforcing the above three links between Greater Eurasia and the Asia Pacific could render the mega-projects in the region more stable and complete". This insight strategically foreshadowed the VCMC, which aims to link Northeast Asia and South Asia via East and Southeast Asia. It's also pertinent to the earlier suggestion that Russia could eventually develop economic ties with India's Japanese AAGC partner. By the end of 2016, it was clear that there were immense promises for Russian-Indian relations. This explains why RIAC partnered with the Vivekananda International Foundation (VIF) to publish an influential report in October 2017 titled "70th Anniversary of Russia-India Relations: New Horizons of Privileged Partnership" ${ }^{10}$. Many experts contributed to it, but the most important, and the ones who wrote the foreword, are Vyacheslav Trubnikov, the former Director of the Foreign Intelligence Service and Ambassador to India, and Kanwal Sibal - former Foreign Secretary and Ambassador to Russia.

\section{The $70^{\text {th }}$ Anniversary of Russian-Indian Relations}

Trubnikov predicted that "it is possible that a new bipolarity could emerge - the United States against China, with Russia and India being the new 'non-aligned' pow-

\footnotetext{
8 Lissovolik Ya. 2016. The Cross-Roads of Eurasia and Asia Pacific. Valdai International Discussion Club. 14 Sept. URL: http:// valdaiclub.com/a/highlights/the-ross-roads-of-eurasia-and-asia-pacific/ (accessed 20.03.2020)

9 Ibid.

10 Popadyuk O, et al. 2017. 70th Anniversary of Russia-India Relations: New Horizons of Privileged Partnership. Russian International Affairs Council, 11 Oct. URL: https://russiancouncil.ru/en/activity/publications/70th-anniversary-of-russiaindia-relations-new-horizons-of-privileged-partnership/ (accessed 20.03.2020)
} 
ers relying on regional systems of international security such as BRICS, the Shanghai Cooperation Organization (SCO), the Association of Southeast Asian Nations (ASEAN), the Eurasian Economic Union (EAEU) and the Collective Security Treaty Organization (CSTO)". He said that "the time to think in large and specific categories is fast approaching", which he predicts will result in a "new paradigm of strategic partner relations between Russia and India". Trubnikov added that "the SCO and BRICS frameworks are large enough to attract China, Pakistan, Afghanistan, Iran and other countries in the Indo-Pacific region to Russia-India bilateral relations in these largescale projects"11.

Sibal stated that "close ties with Russia are a balancing factor in our foreign policy and give us the strategic autonomy that we feel we must have". Although Indian-American ties are not aimed against Russia, he is worried about the impact of Russian-Pakistani ones because some Pakistani voices have "begun to tout a Pakistan China - Russia axis against an India - US axis in the region"12. These fears are ironic because India does not take Russia and China's worries into consideration when expanding its ties with the US, especially military ones, yet it is uncomfortable with much less strategic cooperation between Russia and Pakistan, thus suggesting a double standard, even if unintentionally.

Sibal continued by saying that "the belief in some Russian quarters that Pakistan can be a participant in major SCO or BRICS infrastructure and other projects within the framework of the India - Russia strategic relationship is unlikely to find a positive echo in Indian thinking, given India's seven decades of experience with Pakistan's endemic hostility. Russia's evolving optic on Pakistan is creating a gap in the hitherto strong geopolitical understandings between India and Russia in our region", which reinforces the observation of the present article's authors that a double standard might be at play since India doesn't tolerate any criticism by Russia or anyone else of its ties with the US. It can only be speculated to what end this is being pursued but will hopefully be clarified with time.

Another opinion that Sibal shared was that China currently has what he characterized as the "upper hand" with Russia. He elaborated by saying that it's taking advantage of BRICS+ "for expanding its geopolitical and geoeconomic goals, and, in the process, diminish the relative role of Russia and India in the forum". The former ambassador then talked about India's security dilemma with China regarding its Belt \& Road Initiative (BRI) and its flagship project of the China-Pakistan Economic Corridor (CPEC). He closes his foreword by writing that "China is in a better position to challenge the US and establish a G2 of sorts, an outcome that would be reached at the cost of both India and Russia. The question therefore is whether India and Russia should become partners in this process or refine their strategy in ways that they do not

\footnotetext{
11 Ibid.

${ }^{12} \mathrm{lbid}$.
} 
accelerate the realization of China's geopolitical and maritime ambitions that are now quite evident" ${ }^{\prime 3}$. The innuendo is that Russia and India should jointly balance China, which lays one of the conceptual bases for the Neo-NAM that will be talked about later more in detail.

Trubnikov and Sibal believe that India can assist Russia with finding a balance in an increasingly bipolar world. Their larger report itself in which they prominently contributed mostly covers many of the postulates from the previously mentioned RIAC piece from a year earlier. The authors reminded the reader about some of the main points of that report, namely that bilateral relations are not occurring in a vacuum and that China's movement towards Eurasia is occurring in response to the US' "Pivot to Asia". Although they note that Indian-American relations are improving against deteriorating Russian-American ones, they urge the reader not to see a connection to this coincidence. The experts also encourage the two sides to improve connectivity through the NSTC and a free trade agreement.

One of the report's conclusions is that "historically, Russia and India have not pursued policies in the neighborhood of either country that are geopolitically against their respective interests. This compatibility of geopolitical interests should be maintained. Inter alia, this requires additional consultations between Moscow and New Delhi on current dynamics in South Asia, Central Asia, Middle East, Eastern Europe and East Asia. This can be interpreted as a hint about how uncomfortable India feels about Russia's relations with China and especially Pakistan while also functioning as a deflection from any criticism aimed at Indian-American ones. A visionary proposal made near the end is that India and Russia can profitably cooperate with each other in economic projects in third countries, primarily in Nepal, Bangladesh and Sri Lanka, as well as in Central Asia. In the contemporary context, this suggests Russia's closer cooperation with the AAGC to that effect and is also relevant to the guiding goals of the Neo-NAM ${ }^{14}$. Overall, the report thoroughly analyzes Russian-Indian relations and shares a pragmatic blueprint for their future.

\section{Russian-Indian Relations in the Multipolar Context}

The next expert report to be analyzed is the one written by academic supervisor of the Center for Comprehensive European and International Studies Timofei Bordachev in February 2018 titled "Greater Eurasia in 'the Indian Century"'15. He writes that the US' unipolarity has failed, bringing about chaos instead of bipolarity or multipolarity, and that this dynamic is being weaponized to divide China and India. Bordachev therefore believes that it is particularly important for Russia, China and other Eurasian

\footnotetext{
13 Ibid.

${ }^{14}$ Ibid.

${ }^{15}$ Bordachev T. 2018. Greater Eurasia in 'the Indian Century.' Valdai International Discussion Club. 22 Feb. URL: http:// valdaiclub.com/a/highlights/greater-eurasia-in-the-indian-century/ (accessed 20.03.2020)
} 
states not to allow this chaos to spread to their macroregion, so they should join forces to "[prevent] the formation of a new multipolarity in Greater Eurasia with rival, or simply competing centers of power"16.

Director General of RIAC Andrey Kortunov published a detailed report on China-India relations in May 2018 titled "Indo-Pacific or Community of Common Destiny?" 17 . He believes that the next two decades will determine the emerging world order, and that "it is clear that the epicenter of the struggle is - and will continue to be - the Eurasian continent". It is important to note that Kortunov still regards the ongoing global systemic transition as being in its opening stages and refers to the Steven R. Mann's work "Chaos Theory and Strategic Thought" 18 as relevant for the analysis. According to Mann any changes at the initial stages of complex processes have an outsized influence on the outcome. A tangible progress on the Neo-NAM track may lead to a paradigm change in international relations if it results in tripolarity instead of bipolarity or multipolarity.

Kortunov also believes that "the two competing long-term visions of Eurasia are coming into clash. Each represents the national interests of key players, a combination of regional military, political, and economic strategies, bilateral and multilateral international mechanisms, and corresponding ideological and conceptual designs. Each vision is collecting its coalition, mobilizing its allies, and accumulating its resources. The main battles are yet to come, but the scent of gunpowder is already in the air. Everything points to a protracted and demanding confrontation. Tactical compromises between the two visions are possible and likely even inevitable, though in the long term, the two projects are in no way compatible. In the end, there can be only one winner, and the loser shall be relegated to the fate of being a redundant historical player in the evolution of the Eurasian continent". This developing dichotomy is between the US-backed Indo-Pacific and the Chinese-backed Community of Common Destiny.

These two models have not yet fully formed, and each has their benefits and detriments. Kortunov considers the US' military to be an advantage of the former while its disadvantage is its precarious economic foundation, particularly because the Indo-Pacific does not have an institutionalized economic component. Concerning the later China's Community of Common Destiny model, Kortunov considers its longterm planning to be an advantage but says that the disadvantage "lies in the fears of neighboring states regarding Chinese economic, political, and military hegemony in Eurasia" since the current American hegemony along the periphery of the Eurasian continent strikes many as less burdensome and more bearable than the potential dom-

\footnotetext{
16 Ibid.

${ }^{17}$ Kortunov A. 2018b. Indo-Pacific or Community of Common Destiny? Russian International Affairs Council. 28 May. URL: https://russiancouncil.ru/en/analytics-and-comments/analytics/indo-pacific-or-community-of-common-destiny/ (accessed 20.03.2020)

${ }_{18}$ Mann S. Chaos Theory and Strategic Thought. Parameters. Autumn 1992. URL: https://pdfs.semanticscholar.org/2d4c/ed ff480f9962dedd7bd4997f4b7a29e25276.pdf (accessed 20.03.2020)
} 
inance of Beijing ${ }^{19}$. Kortunov characterizes India as a "decisive swing state" because it could choose either of these two models, and both the US and China are competing for its participation in their respective projects. He says that it would not be an exaggeration to say that for the present, and moreover for the future, a partnership with India is no less important to the US than their Cold War alliance with Japan was. India is moving closer to the US out of fear that China's infrastructure projects in the Indian Ocean might have a secret security motive. Nevertheless, Kortunov thinks that it is unlikely that India will be able to avoid junior partner status in the USA's Indo-Pacific with all the accompanying costs if it decides to double down on this partnership in order to contain China.

When it comes to his homeland's interests, Kortunov writes that the Indo-Pacific does not provide for Russia to have a role there at all, but "a standoff between the maritime and continental parts of Eurasia would clearly be preferable to Russia than the hypothetical version of a close American-Chinese cooperation as the G2, which would certainly reduce the value of Moscow as a partner not only in Washington's eyes, but in Beijing's as well. But the costs of a new Eurasian bipolarity for Moscow would in any case outweigh possible benefits: Russian policy in Eurasia would lose its flexibility, and many traditional partnerships, such as with Vietnam and India, would be jeopardized"20.

Kortunov thinks that the Community of Common Destiny is the best option for Russia, but warns that Moscow must not behave like a spoke attached to the central Chinese Eurasian axis, but as a parallel axis, albeit one smaller in diameter, which is why it must enter the Community of Common Destiny with its own Eurasian integration project (EAEC) and not empty-handed. Although unintentional, Kortunov made a strong argument in favor of the Neo-NAM (whether independently pursued or carried out jointly with India) in order to achieve a strategic balance with China and thus become a more equal partner to it. He added that India will face the same challenge if it should decide in favor of the Community of Common Destiny so it would be logical for Delhi to perform a system-forming function for South Asia, similar to the one that Russia must implement in Central Eurasia. At the same time, though, the Indian leadership must understand that the time of exclusive spheres of influence enjoyed by the great powers are a thing of the past, that it is no longer possible to count on the unconditional loyalty of even the closest neighbors and partners, like Sri Lanka, Bangladesh, and Nepal, and that it will be necessary to fight hard for their attention and benevolence ${ }^{21}$.

\footnotetext{
${ }^{19}$ Kortunov A. 2018. Indo-Pacific or Community of Common Destiny? Russian International Affairs Council. 28 May. URL: https://russiancouncil.ru/en/analytics-and-comments/analytics/indo-pacific-or-community-of-common-destiny/ (accessed 20.03.2020)

20 lbid.

${ }^{21}$ Ibid.
} 
It seems to be a correct assessment since India's regional policy has been marked by coercive actions against its neighbors lately. For example, India imposed a failed informal blockade against Nepal in $2015^{22}$ because it believed that the country's thennewly passed constitution was not to the advantage of the southern plains-dwelling Madhesis with whom India shares close economic, historical, and demographic ties. It was more successful, though, with backing democratic regime changes in Sri Lanka ${ }^{23}$ and the Maldives ${ }^{24}$. Another example of India's regional coercive policy has been its co-opting of Bangladesh's ruling party in order to turn that country into its junior partner, though this has upset large segments of the population ${ }^{25}$.

Kortunov's analysis also channels the ideas of former US Secretary of State Henry Kissinger. He referenced that statesman's strategic precepts when writing that "in any geopolitical triangle, the corner whose relationship with each of the other two angles is better than their relationship with each other is in the most favorable position", so in keeping with this classic of geopolitics, Russia should theoretically be interested in maintaining a certain level of tension in Sino-Indian relations in order to occupy the most favorable position in the Russia - China - India triangle. At the same time, however, Kortunov writes that Russia does not stand to benefit from an exacerbation of Sino-Indian conflicts, so it should be a priority for Russian foreign policy (of no less importance than restoring relations with the West!) to seek ways to overcome disagreements between India and China and to strengthen cooperation between the two, which could be accomplished by focusing more on RIC "which was to some extent swallowed up within the BRICS structure" 26 . Since Russia and India are in similar strategic positions vis-a-vis China, the present article's authors believe that the joint establishment of the Neo-NAM could help them both improve their standing with it, both bilaterally and collectively.

Kortunov concluded his analysis by writing that the Community of Common Destiny is better for Russia than the Indo-Pacific, but it "does not in any way signify a return to the old idea of Yevgeny Primakov, expressed during his visit to Delhi in late 1998, about the trilateral cooperation of Russia, China, and India existing to counter the monopolar American world". According to his assessment, the unipolar American

\footnotetext{
${ }_{22}$ Nepal Blockade: Six Ways It Affects the Country. BBC. 12 Dec. 2015. URL: https://www.bbc.com/news/world-asia-35041366 (accessed 20.03.2020)

${ }^{23}$ Chalmers J., Miglani S. Indian Spy's Role Alleged in Sri Lankan President's Election Defeat. Reuters. 18 Jan. 2015. URL: https://www.reuters.com/article/us-sri-lanka-election-india-insight/indian-spys-role-alleged-in-sri-lankan-presidentselection-defeat-idUSKBNOKR03020150118 (accessed 20.02.2020))

${ }^{24}$ Mitra D. India's Strategy on Maldives Delivered Results, Says Ex President Nasheed. Wire. 20 Feb. 2019. URL: https:// thewire.in/south-asia/indias-strategy-on-maldives-delivered-results-says-ex-president-nasheed (accessed 20.03.2020)

${ }^{25}$ Ahmed I. In Bangladesh, a Student's Murder Opens a Window on Rising Anti-India Sentiment across the Border. Scroll. in. 10 Oct. 2019. URL: https://scroll.in/article/939979/in-bangladesh-a-students-murder-opens-a-window-on-rising-antiindia-sentiment-across-the-border (accessed 20.03.2020)

${ }^{26}$ Kortunov A. 2018. Indo-Pacific or Community of Common Destiny? Russian International Affairs Council. 28 May. URL: https://russiancouncil.ru/en/analytics-and-comments/analytics/indo-pacific-or-community-of-common-destiny/ (accessed 20.03.2020)
} 
world has not come to pass nor will it. The balance of power in the world has changed alongside the rules of the game of world politics. Moscow's biggest mistake would be to try to fill the new Eurasian project with old geopolitical content. Equally erroneous would be any attempt to present the Eurasian project and the development of relations between individual participants and external players as a type of Zero-sum game". If China's vision succeeds, then "the implementation of the Common Destiny would see the United States gradually lose its imperial status and turn into primus inter pares the most powerful of several great powers paving the way into the $22^{\text {nd }}$ century" ${ }^{27}$.

Kortunov proposed four scenarios in his next analysis published a week afterwards in June 2018 titled "China and the US in Asia: Four Scenarios for the Future"28. He wrote that the future will either see a "Washington consensus 2.0" of strengthened American influence, a "China-India Axis", a "multipolar balance of power", or a "new bipolarity" of "maritime democracies" and "continental autocracies"29. The first one would make Russia more strategically important for China, just as the second scenario would see the strengthening of RIC. Although Kortunov is more pessimistic about the prospects for Russia in the last two scenarios, the present article's authors think that they could still be advantageous, though only if Russia succeeds in establishing the Neo-NAM, whether on its own or in joint cooperation with India. That would enable it (or those two together) to better balance between all relevant players.

Kortunov continued his analytical series on this topic in a piece published in February 2019 titled "Heartland Reunion: Geopolitical Chimera or Historical Chance?"30. His article began by referencing MacKinder's heartland theory, but then he expanded upon the concept by stating that the "inner crescent" of China and India is the $21^{\text {st }}$-century's heartland of the Eastern Hemisphere. It therefore follows that the future of Chinese-Indian relations will decide the future of Eurasia according to Kortunov's model, and this will then decide the future of the world order. At a quick glance, he notes that "it would seem that there are no fundamental obstacles to the consolidation of the heartland" since India and China share similar positions towards a lot of issues and are "revisionist" because they want to reform the world order to improve their role within it. Digging deeper, however, he points out how there is a real rivalry between them which he attributes to their different forms of government, internal demographic-ethnic diversities, his observation that China is a lot like an EU state while India is more like the EU in general because of its internal diversity, their unique histories, regional economic competition, unresolved grudges over their 1962

\footnotetext{
27 Ibid.

${ }^{28}$ Kortunov A. 2018. China and the US in Asia: Four Scenarios for the Future. Russian International Affairs Council. 8 June. URL: https://russiancouncil.ru/en/analytics-and-comments/analytics/china-and-the-us-in-asia-four-scenarios-for-thefuture/ (accessed 20.03.2020)

${ }^{29}$ lbid.

${ }^{30}$ Kortunov A. 2019. Heartland Reunion: Geopolitical Chimera or Historical Chance? Russian International Affairs Council. 8 Feb. URL: https://russiancouncil.ru/en/analytics-and-comments/analytics/heartland-reunion-geopolitical-chimera-orhistorical-chance/ (accessed 20.03.2020)
} 
war, and military and economic asymmetries that result in China being the objectively stronger of the two. That last point might be another argument in support of India jointly forming the Neo-NAM with Russia.

Moving along, Kortunov notes that today we are witnessing an attempt by the United States to replicate the successful approaches of Henry Kissinger taken in the 1970's and to build a Eurasian geopolitical triangle. "The difference is that the USSR is replaced by China, and China is replaced by India. This explains the increased attention of the United States to New Delhi and the persistent attempts to involve India in multilateral groupings that include allies of the United States that are located on the island periphery of the Eurasian continent, namely Japan and Australia (the concept of a "democratic Indo-Pacific"). If Washington had succeeded in achieving the sustainable institutionalization of these groupings in the form of a military-technical alliance similar to NATO, this would have created long-term guaranteed preventing the consolidation of the Heartland" ${ }^{31}$. Although problematic, Kortunov is not all that worried because he believes that any format of allied relations with Washington is politically unacceptable for the Indian elite, which is pushing for the preservation of the country's strategic independence. What is more, India cannot sacrifice its continental Eurasian partners (primarily Moscow and Tehran) - not even for the sake of friendship with Washington.

That perspective is disputable, however. India agreed to comply with the US' sanctions regime against Iran despite the Islamic Republic being its traditional oil partner $^{32}$. Concerning Russian-Indian relations, the Stockholm International Peace Research Institute revealed in its "Trends In International Arms Transfers, 2018”33 report, released in early 2019, that "Russia accounted for 58\% of Indian arms imports in 2014 - 2018, compared with 76\% in 2009 - 2013", a change that Indian media reported amounts to a $42 \%$ drop $^{34}$ since Russian wares have been gradually replaced with the American, Israeli, and French ones. The takeaway from these two trends is that India is indeed moving closer to the US on some accounts at the expense of some of its preexisting strategic ties with Iran and Russia.

With Kissinger in mind, Kortunov says that "right now, Russia's relations with China and India are better than those between China and India, meaning that it occupies the most advantageous position in this triangle. Based on this logic, we can assume that the consolidation of the Eurasian Heartland around the China - India axis would entail a further shift in the Eurasian center of gravity towards the south

\footnotetext{
31 Ibid.

32 India Has Ended Iranian Oil Imports: Envoy. France 24/ 23 May 2019. URL: https://www.france24.com/en/20190523-indiahas-ended-iranian-oil-imports-envoy (accessed 20.03.2020)

33 Trends in International Arms Transfers, 2018. Stockholm International Peace Research Institute. Mar. 2019. URL: https:// www.sipri.org/sites/default/files/2019-03/fs_1903_at_2018_0.pdf (accessed 20.03.2020)

${ }^{34}$ Russian Arms Exports to India Fell by 42\% between 2014-18 and 2009-13: Report. Livemint. 12 Mar. 2019. URL: https://www. livemint.com/news/india/russian-arms-exports-to-india-fell-by-42-between-2014-18-and-2009-13-report-1552330101285. html (accessed 20.03.2020)
} 
of Russia's borders. This would marginalize Russia even further as a participant in the Eurasian community" (Kortunov 2019). Still, he warns, it is safe to predict that attempts to capitalize on the contradictions between China and India will inevitably raise suspicions both in Beijing and in New Delhi, cause them to doubt the sincerity of Russia's actions, which is why he suggests placing more of an importance on RIC and getting it involved in Syria, Afghanistan, and the Arctic in order to maintain trust between the three countries. Even so, Kortunov still believes that "whatever Russia's role in the consolidation of the Eurasian Heartland, it will by no means be decisive. China - India relations have their own internal logic and their own dynamics that no external player (be it the United States, the European Union or Russia) can change" 35 . This is also disputable since the joint establishment of the Neo-NAM with India could totally change the dynamic that Kortunov described.

The case can be made that the Neo-NAM might be regarded suspiciously by China, but the possible improvement of Russian-Pakistani relations in parallel with it might ease some of these concerns. If Russia goes forward with this, then Kortunov's prediction that its role in integrating the Eurasian Heartland "will by no means be decisive" might no longer remain relevant. Russia's role could instead be extremely decisive since this development would be occurring in the early stages of the global systemic transition (Jacobsen, Troels 2017), which according to Mann's application of chaos theory to strategic thought, would allow it could have an outsized influence over this process' outcome in the next two decades that Kortunov earlier forecast that it would be decided by. The Neo-NAM could also serve as Russia's gateway to the Indo-Pacific through India just like how Russia serves as India's gateway to other regions such as Northeast Asia, the Arctic, and Central Asia like was earlier written in the research.

\section{The Neo-NAM}

Having framed the evolving strategic context of Russian-Indian relations, it's now time to talk about the two articles published at one of Russia's top think tanks, the Valdai Club, formally proposing the creation of the Neo-NAM. The first one was written by program director Oleg Barabanov and released in May 2019 under the title "China's Road to Global Leadership: Prospects and Challenges for Russia"36. Of relevance to the present research, he wrote that the fact that a new bipolar world will crystallize in the medium term with the United States and China in opposition to one another shouldn't lead to a zero-sum outcome because partnering with one country does not necessarily mean the automatic end to partnership with another (or even enmity). In fact, he

\footnotetext{
${ }^{35}$ Kortunov A. 2019. Heartland Reunion: Geopolitical Chimera or Historical Chance? Russian International Affairs Council. 8 Feb. URL: https://russiancouncil.ru/en/analytics-and-comments/analytics/heartland-reunion-geopolitical-chimera-orhistorical-chance/ (accessed 20.03.2020)

${ }^{36}$ Barabanov O. 2019. China's Road to Global Leadership: Prospects and Challenges for Russia. Valdai International Discussion Club. 14 May. URL: http://valdaiclub.com/a/highlights/china-s-road-to-global-leadership/ (accessed 20.03.2020)
} 
suggests that Russia could strike a balance between the both if it pioneers the creation of a "new Non-Aligned Movement". Should it eventually find success in this endeavor, Barabanov wrote, then "other large countries do not necessarily have to take one side of the barricade, but, on the contrary, would be better off if they maintain some kind of neutrality and coordinate their efforts" through this network. Nevertheless, he also cautioned that if pursued in a too radical and uncompromising way, the logic of the "new non-aligned movement" can become a challenge to the consolidation and unity of Eurasia, which is the top priority for the SCO and other projects ${ }^{37}$. In other words, the Neo-NAM is a promising concept in theory, but must be carefully implemented in practice (Kabi 2002).

Shortly after the publication of Barabanov's proposal, Alexey Kupriyanov, a fellow member of the Valdai Club and Researcher of the Sector of International Organizations and Global Political Regulation of the Department of International Political Problems at the Institute of World Economy and International Relations (IMEMO) in Moscow, elaborated a bit on Indian geostrategy in a manner which in hindsight set the basis for his subsequent joint Russo-Indo "Peaceful Development Movement" proposal a few months later. He and several other experts were interviewed at the time by Valdai Club's Deputy Editor-in-Chief Anton Bespalov in the July 2019 article "Goodbye Pacific Rim, Hello Indo-Pacific?" 38 . Kupriyanov insisted that India is trying to maintain a balance between the US and China in order to mutually benefit from both the Indo-Pacific and BRI. According to him, the Indo-Japanese-Indonesian version of the Indo-Pacific and the Belt and Road project could be integrated if both sides are interested and have the political will: these initiatives increase Eurasia's transport potential ${ }^{39}$. That particular passage suggests a combination of the two that might create a new opportunity for pioneering a middle/third way in an increasingly bipolar world. With a view towards this, Kupriyanov declared that it is time for Russia to form its own vision of Indo-Pacific and, importantly, bring it to the countries of the region, which he then elaborated on a few months later ${ }^{40}$.

Coinciding with Prime Minister Modi's participation in the September 2019 EEF, during which time the VCMC was launched, Kupriyanov co-authored a Valdai Club report with Alexander Korolev, junior research fellow at the Centre for Comprehensive European and International Studies at the Higher School of Economics in Moscow, titled "The Eurasian Chord and the Oceanic Ring: Russia and India as the Third Force in a New World Order" 41 . Their report started off by stating that there's a "Second Cold

\footnotetext{
${ }^{37}$ Ibid.

${ }^{38}$ Bespalov A. 2019. Goodbye Pacific Rim, Hello Indo-Pacific? Valdai International Discussion Club. 1 July. URL: http:// valdaiclub.com/a/highlights/goodbye-pacific-rim-hello-indo-pacific/? (accessed 20.03.2020)

${ }^{39}$ Ibid.

40 Ibid.

${ }^{41}$ Kupriyanov A., Korolev A. 2019. The Eurasian Chord and the Oceanic Ring: Russia and India as the Third Force in a New World Order. 11 September. URL: http://valdaiclub.com/a/reports/the-eurasian-chord-and-the-oceanic-ring/ (accessed 20.03.2020)
} 
War" nowadays between the US and China. In their opinion, it is a strictly imperialistic affair, for there is no particular difference between the US and China since the they are concerned with expanding their influence, gaining access to resources, promoting their goods on the markets of dependent countries, and claiming the mantle of the global hegemon within the global market system. In response to this seemingly bipolar system, the authors wrote that Moscow and New Delhi may respond by forming an unofficial, non-military alliance, which could be termed the Peaceful Development Movement, and that the aim of forging such a space of co-development would be to continue positive globalization while also searching for fairer alternatives to the existing world order. By eschewing the decision to take a side in the Second Cold War, both countries could then "profit from maintaining strategic autonomy for as long as possible in order to benefit from trade with both parties while avoiding commitments"

Kupriyanov and Korolev do not consider China's Community of Common Destiny or the US' Western democratic model to be suitable replacements for the role that ideology used to play in the First Cold War. Instead, they write that "what we are witnessing today is more reminiscent of the period before World War I, an imperialist war, with powers' purely economic rivalry over colonies, resources, and markets". Wanting to avoid backing the wrong horse, it is most sensible for the "key/swing states" of Russia and India to pool their efforts towards creating a middle/third way between the US and China by creating issues-based coalitions that prevent unipolar or bipolar arrangements as opposed to only balancing between them (Oosterveld et al. 2014). Some of the ideas mentioned in the " 100 Postulates on Russia-India Relations" and the follow-up report on the "70th Anniversary of Russia-India Relations: New Horizons of Privileged Partnership" could prove themselves useful in this respect. According to Kupriyanov and Korolev, Russia and India are already geopolitically complementary to one another because "without Russia's participation, no one can access the Arctic shelf's resources", while "without India, there are no approaches to the resources of East Africa" ${ }^{\prime 3}$. This means that they could potentially become a force to be reckoned with if they coordinated their efforts through the Neo-NAM.

The authors' following assessment of the interplay between the US, China, Russia, and India is convincing. They write that "a change in the status of either [Russia or India] would entail a simultaneous shift for the other. For example, if Russia enters into an alliance with China, the latter will become vastly more powerful. If the United States enters into an alliance with India, China will be significantly weakened. If Russia or India suddenly joins the US, this will spell defeat for China, which will have to forget about its maritime ambitions and start fortifying its borders instead. If Russia

\footnotetext{
42 Bespalov A. 2019. Goodbye Pacific Rim, Hello Indo-Pacific? Valdai International Discussion Club. 1 July. URL: http:// valdaiclub.com/a/highlights/goodbye-pacific-rim-hello-indo-pacific/? (accessed 20.03.2020)

${ }^{43}$ Kupriyanov A., Korolev A. 2019. The Eurasian Chord and the Oceanic Ring: Russia and India as the Third Force in a New World Order. 11 September. URL: http://valdaiclub.com/a/reports/the-eurasian-chord-and-the-oceanic-ring/ (accessed 20.03.2020)
} 
and India decide to take China's side, this will spell defeat for the United States, because China will enjoy an inexhaustible supply of resources" ${ }^{\prime 4}$. As for India, a formal military and political alliance with either of the two great powers will mean a dramatic worsening of relations with the other. As it grows closer to the United States, relations with China will deteriorate, resulting in, first and foremost, escalation of border conflicts. This scenario is such a remote possibility because it is totally incompatible with India's development goals. Significant closeness between New Delhi and Beijing is also unlikely in the foreseeable future. There is no advantage for India to enter the orbit of its main rival in the race for regional leadership, which would work against India's bid to become a great power in its own right. "In this context, China's negative reaction to the Indo-Pacific concept is unsurprising. The Chinese establishment sees it as a means of containing Beijing. Besides, closer ties with China would have a negative effect on India's relations with the United States, one of its most important trade partners and a supplier of defense technology. Constructive relations with the US are also a key factor in India joining the Nuclear Suppliers Group (NSG)"45. As a result, "developments are prodding Russia and India into forming an informal alliance, a Non-Aligned Movement 2.0, which could be more aptly termed the Peaceful Development Movement $(\mathrm{PDM}){ }^{\prime 46}$.

Rounding out the remainder of their "Peaceful Development Movement" proposal, Kupriyanov and Korolev write how the very principles that underpin formation of international alliances have changed since the first NAM's founding, which is why under these circumstances, it makes no sense to revive NAM or create NAM 2.0. Still, the authors of the present article believe that their proposal should still be referred to as the Neo-NAM for simplicity's sake. However one chooses to refer to it, those two experts believe that the new movement should be based on new standards and new rules of the game, specifically what President Trump calls "principled realism", under which states are guided primarily by their own interests while putting forward a set of principles they agree not to breach, which is a really useful suggestion. More specifically, these are the seven principles that they envisage characterizing this joint Russian-Indian global network:

1. Support for democracy with national features, rejection of coups as a means of gaining power;

2. Non-interference in the internal affairs of other states with the exception of cases where the authorities commit mass crimes and only after such cases are investigated;

3. Keeping to the positive globalization course while searching for fairer alternatives to the existing world order, including reforms of the UN in the interests of developing nations; 
4. Seeking to avoid military conflicts through peacekeeping and stable development, which does not mean a commitment to unbounded pacifism - each state reserves the right to self-defense;

5. Aversion to unilateral sanctions, trade wars, or any other types of protectionism used as a means of foreign policy;

6. Non-participation in exclusive global or regional military political blocs involved in the Second Cold War;

7. Promoting trade and economic liberalization by signing free trade agreements with foreign partners and supporting multilateral institutions and integration unions ${ }^{47}$.

Kupriyanov and Korolev also asserted that the important thing in this context is to understand that PDM is precisely a movement, an informal alliance held together by common goals rather than a rigid framework, before writing that "naturally, no one has the right to prohibit India from solidifying relations with the US, nor Russia from doing the same with China. But these relations should not be reduced to vassalage, something that would automatically make the PDM redundant. On the contrary, member-states must see to it that their PDM partners improve relations with partners outside the Movement. In effect, this is an extension of the 'multi-alignment' concept characteristic of Indian foreign policy". These points are pragmatic enough, but do not touch upon India's efforts to tacitly pressure Russia to turn away from Pakistan, which New Delhi perceives through the perspective of zero-sum outcomes as opposed to the spirit of "multi-alignment"/ "strategic autonomy" that it claims to support for all of its partners including Russia. Justifying their proposal for Russia and India to lead the Neo-NAM, Kupriyanov and Korolev write how both countries are expanding their influence across the globe and that no other pair of countries of comparable weight can boast such strong historical and political ties and a total lack of conflicts in the past and foreseeable future. They also predict that "middle-sized countries would play an important role in the future PDM, as they are essential to the stability and systemic nature of the Movement", and that blocs of states such as the European Union and the Association of Southeast Asian Nations (ASEAN) but also any other organizations (MERCOSUR, the Southern African Development Community - SADC, the Economic Community of West African States - ECOWAS, etc.) could join as well because they all share the network's "neutral stance".

\section{Recent Official Assessments on Russian-Indian Relations}

Kupriyanov and Korolev's Neo-NAM proposal represents the culmination of all the trends in the Russian-Indian relationship that were earlier discussed in this article, so it's worthwhile to see if official assessments from both countries signal any support

\footnotetext{
${ }^{47}$ Kupriyanov A., Korolev A. 2019. The Eurasian Chord and the Oceanic Ring: Russia and India as the Third Force in a New World Order. 11 September. URL: http://valdaiclub.com/a/reports/the-eurasian-chord-and-the-oceanic-ring/ (accessed 20.03.2020)
} 
for the trajectory that they described. The first strong sign that there is serious interest in moving in this direction came just a week before the EEF on 27 August, 2019, when Indian Ambassador to Russia D.B. Venkatesh Varma gave a brief interview to WION, one of his country's media outlets ${ }^{48}$. He argued that Russia increasingly looks at India as a partner not just in regional context but also as a global player. "New Delhi's view of Moscow is that our relationship with Russia remains one of the most important relationships in a fast-changing world. We see Russia as a partner, a very reliable partner, a long term partner and that is also reflected in the relationship between PM Modi and President Putin," he said ${ }^{49}$. On the eve of Prime Minister Modi's visit to the EEF, TASS published an exclusive interview with the Indian leader where he added some crucial insight into the spirit of relations articulated by Ambassador Varma ${ }^{50}$. He said that India and Russia have similar opinions on almost all issues on the international agenda. And if they do not coincide, then the difference is small, which is why "we speak from a single point of view in multilateral formats"51. These points were repeated during the press conference that President Putin and Prime Minister Modi held during the event in Vladivostok ${ }^{52}$. The Russian leader said that Russia and India reaffirmed their close positions on key global and regional issues during the discussion of international affairs; states are coordinating their foreign policy positions at such major international forums as the UN, the G20, the Shanghai Cooperation Organization and BRICS. Russia and India are working together to ensure security and stability in Asia, and the Pacific and Indian oceans. The Indian leader, meanwhile, enthusiastically proclaimed that "both countries understand that we need a multipolar world to achieve peace and stability. Our cooperation on this issue and coordination will be essential in reaching this goal. This is why we must develop our cooperation in BRICS, the SCO and other organizations and venues... As always, today we held open and meaningful talks on major international and regional issues. India wants to see Afghanistan independent, safe, united, peaceful and democratic. Both our countries are against external interference in the affairs of any state. In addition, we held a useful discussion on India's concept of an open and inclusive Indo-Pacific Region". These ideas were elaborated on in their joint statement ${ }^{53}$, which importantly included several key points that perfectly complement the proposal that the two Valdai Club experts published a week later, but which they were presumably working on long before then in order to create a model

\footnotetext{
${ }^{48}$ Sibal S. Russia Is a Long-Term Reliable Partner: India. WION. 27 Aug. 2019. URL: www.wionews.com/india-news/russia-isa-long-term-reliable-partner-india-245892 (accessed 20.03.2020)

${ }^{49}$ lbid.

50 PM Modi's Interview to TASS, Russian News Agency. Narendra Modi. 4 Sept. 2019. URL: www.narendramodi.in/pm-modiin-an-interview-to-tass-546282 (accessed 20.03.2020)

51 lbid.

52 Press Statements Following Russian-Indian Talks. President of Russia. 4 Sept. 2019. URL: en.kremlin.ru/events/president/ news/61442 (accessed 20.03.2020)

53 Joint Statement Following the $20^{\text {th }}$ India-Russia Annual Summit 'Reaching New Heights of Cooperation through Trust and Partnership'. President of Russia. 4 Sept. 2019. URL: en.kremlin.ru/supplement/5438 (accessed 20.03.2020)
} 
for taking the Special and Privileged Strategic Partnership between these two countries further into the future.

Paragraph 24 of the document reiterates that they attach great importance to the development of the International North-South Transport Corridor (INSTC), while paragraph 46 speaks about how both Sides noted the high level of political dialogue and cooperation between the countries, including at the UN, and agreed to deepen it further, which showed their interest in strengthening their bilateral cooperation in multilateral frameworks. The next paragraph built upon that theme by asserting that the sides stressed the imperative of further strengthening of multilateralism, with paragraph 52 specifying that they would pay particular attention to doing so within the SCO in order to further strengthen the Organization as an important pillar of the emerging multi-polar world order based on equal and indivisible security. Paragraph 57 then adds that they will do the same within the G20 and other international organizations and fora with a view to facilitate the early resolution of key international issues. The first third-party state in which they're coordinating their actions was revealed in paragraph 71 to be Afghanistan, where "the sides will continue intensive discussions". Paragraph 73 added economic and humanitarian dimensions to their coordination in third states by disclosing that they agreed to continue to step up assistance to Syria with a view to reconstruction, including the creation of conditions for the return of refugees and temporarily displaced persons. The next paragraph included yet another country into the growing list of states where they're actively coordinating their activities, where it is shown that the leaders expressed their determination to continue mutually beneficial and legitimate economic and commercial cooperation with Iran. Considering the official trend of Russian-Indian coordination in third states, it is little wonder that paragraph 76 directly informed the world that it was agreed to explore mutually acceptable and beneficial areas of cooperation in third countries especially in the Central Asia, South East Asia and Africa, with paragraph 79 stating that India and Russia as stakeholders in this common space (namely "Asia and the Pacific region") agreed to intensify consultations on complementarities between integration and development initiatives in greater Eurasian space and in the regions of Indian and Pacific Oceans ${ }^{54}$.

Taken together, Russian-Indian cooperation in third countries officially aims to encompass the geostrategically central part of the Eastern Hemisphere (the Middle East, Central Asia, South East Asia, Africa, and their respective home regions of North Eurasia and South Asia), with only Europe and East Asia left out of their officially unnamed model of comprehensive cooperation across this half of the world. It is here where Kupriyanov and Korolev's Neo-Nam proposal finds a fitting role in adding substance to this ambitious but vaguely described geopolitical goal by suggesting the seven guiding principles that were cited in the previous section of this article and elab-

\footnotetext{
${ }^{54}$ Joint Statement Following the $20^{\text {th }}$ India-Russia Annual Summit 'Reaching New Heights of Cooperation through Trust and Partnership'. President of Russia. 4 Sept. 2019. URL: en.kremlin.ru/supplement/5438 (accessed 20.03.2020)
} 
orating a little bit about the importance of each. Conceptualizing their practically panhemispheric cooperation model as the PDM (Neo-NAM) underscores the intended neutrality and balancing purpose of this nascent network (Agius, Karen 2011), but their visionary work could be taken to the next level by a more in-depth discussion of the challenges and opportunities inherent to this proposed structure.

\section{Challenges \& Opportunities}

The Neo-NAM's guiding principles and the official vision of pan-hemispheric cooperation articulated in the Russian-Indian joint statement at the EEF are greatly challenged by the US' weaponization of sanctions for geopolitical ends, particular as they relate to Iran. American "secondary sanctions" pressure already compelled India to stop purchasing Iranian energy in May 2019, which raises questions about how sincere the country is when it comes to its commitment to continue mutually beneficial and legitimate economic and commercial cooperation with Iran. It might very well be that the word "legitimate" is the loophole that India is relying on to avoid scrutiny from its Russian partner for abandoning what used to be one of its largest energy partners in the world and which crucially functions as the irreplaceable transit state for the NSTC. Although unilateral American sanctions are illegitimate in terms of international law, the word "legitimate" itself is never described in the joint statement and can therefore be subject to interpretation by both sides. So too, however, can Russia rely on the same wording for the exact same reasons. Interfax reported in February 2020 that the stateowned Russian Railways company was pulling out of a $€ 1.2$ billion plan to modernize Iran's rail network in order to comply with a different set of American sanctions that were promulgated the month prior ${ }^{55}$. In hindsight, Russia might have devised a feasible workaround to continue improving Iran's connectivity infrastructure had India defied the American sanctions first and signaled that it had the political will to abide by paragraph 3 of its earlier cited joint statement with Russia which declared that the India-Russia ties have never been and will not be susceptible to outside influence ${ }^{56}$. Going forward, if the US' weaponization of sanctions becomes the rule for weakening Russian-Indian relations in third-party states and not the exception like it might have been in Iran due to America's long-running objective of isolating the Islamic Republic, then Moscow and New Delhi will have to either devise the aforementioned proposed workaround or abandon the Neo-NAM completely. Under that scenario, the article's authors believe that the first option is obviously the most ideal.

\footnotetext{
55 РЖД собрались выйти из проекта в Иране на фоне новых санкций к этой стране [Russian Railways Gathered in Iran Against the Background of New Sanctions to This Country]. Интерфакс. 25.02.2020. URL: www.interfax.ru/ business/696638 (accessed 20.03.2020) (in Russian)

56 Joint Statement following the $20^{\text {th }}$ India-Russia Annual Summit 'Reaching New Heights of Cooperation through Trust and Partnership'. President of Russia. 4 Sept. 2019. URL: en.kremlin.ru/supplement/5438 (accessed 20.03.2020)
} 
Still, the US' sanctions pressure creates unmistakable problems for the viability of the Neo-NAM's proposed cooperation in Central Asia in the event that the eastern branch of the NSTC to Afghanistan and the neighboring former Soviet Republics never fully enters into force despite the terminal port of Chabahar presently enjoying a curious sanctions waiver for the time being. The possibility that Iran might never become a bridge for linking the Russian and Indian economies via Azerbaijan has increased the appeal of what the article's authors describe as the Trans-Arabian Corridor (TAC). Sputnik reported in December 2019 that Israel has shared its flagship connectivity plan connecting the Mediterranean with the Gulf and India with Indian External Affairs Minister Jaishankar on the sidelines of the Mediterranean Dialogues forum ${ }^{57}$. Although details are scant, the unstated selling point of the proposal is that India wouldn't need to risk the US' "secondary sanctions" wrath by continuing to invest in overland connectivity to Europe via Iran and Russia but could simply replace that multimodal corridor with the geographically shorter TAC, which isn't likely to ever be subject to American sanctions since its GCC, Jordanian, and Israeli partners are Washington's close allies. In the event that this happens, then the prospect of economic cooperation between Russia and India in Afghanistan, Central Asia, and Iran would greatly diminish, thus reducing the Neo-NAM's on-the-ground visibility in the geostrategic Heartland of Eurasia and therefore making their coordination along the Indo-Pacific Rimland regions of Africa, South Asia, and Southeast Asia all the more important for this vision's viability.

There are also challenges to cooperation in that region too, however, owing to India's new military-strategic partnership with the US under the aegis of the so-called "Indo-Pacific" strategy ${ }^{58}$. Tellingly, former Prime Minister Medvedev criticized this joint Indian-American blueprint during an interview with the Bangkok Post ahead of his trip to Thailand for the ASEAN Summit less than two months after Prime Minister Modi said during his press conference with President Putin that they held a useful discussion on India's concept of an open and inclusive Indo-Pacific Region. The Russian government apparently wasn't convinced by the Indian leader after Medvedev described the "Indo-Pacific" strategy as a serious challenge for ASEAN countries, since it can weaken the Association's position and strip it of its status as a key player in addressing regional security problems. Furthermore, it is at odds with ASEAN fundamental principles, such as non-alignment and non-aligned statu ${ }^{59}$. He was careful not to directly accuse India of this, but he still seems to have been taking a swipe at it

\footnotetext{
${ }^{57}$ Israel Shares Its Connectivity Routes Allowing India to Bypass Strait of Hormuz. Sputnik. 9 Dec. 2019. URL: sputniknews. com/world/201912091077519931-israel-shares-its-connectivity-routes-allowing-india-to-bypass-strait-of-hormuz/ (accessed 20.03.2020)

58 Indo-Pacific Strategy Reporty. Department of Defense. 1 June 2019. URL: media.defense.gov/2019/Jul/01/2002152311/-1/1/1/DEPARTMENT-OF-DEFENSE-INDO-PACIFIC-STRATEGY-REPORT-2019.PDF (accessed 20.03.2020)

${ }^{59}$ Dmitry Medvedev's Interview with the Bangkok Post. Government of The Russian Federation, 3 Nov. 2019. URL: m.government.ru/en/news/38265/ (accessed 20.03.2020)
} 
in this respect, one that was echoed by Foreign Minister Lavrov during his speech at India's Raisina Dialogue in January 2020. Russia's top diplomat declared that the West aim in using the term "Indo-Pacific" instead of "Asia-Pacific" in matters of cooperation is to contain China, and "Indian friends are smart enough to understand that. It's not even hidden...We are not against terminology, but it should be understandable. When people say we want to develop cooperation in Asia-Pacific as Indo-Pacific strategy, we asked how it is different; we were told it is more democratic. We don't think so. It is rather tricky. We have to be careful about the terminology which looks benign but is not. Terminology should be unifying, not divisive. Neither Shanghai Cooperation Organization (SCO) nor BRICS is exclusionary" ${ }^{\prime \prime}$. These criticisms weren't untoward considering just how successful President Trump's first-ever visit to India turned out to be a little more than a month later in February 2020, during which time their joint statement announced the creation of what was described as a comprehensive global strategic partnership ${ }^{61}$.

Should India be successful in resisting American pressure to function as its proxy for "containing" China (and it's thus far uncertain whether it even intends to push back against its new "comprehensive global strategic partner's" implied demands), then there are considerable opportunities for it to develop the Neo-NAM with Russia across the Indo-Pacific Rimland (Mishra 2016). The Vladivostok-Chennai Maritime Corridor (VCMC) was already discussed at the beginning of this article but deserves to be mentioned once again in this new context. India's South Asian partners such as Bangladesh could join their larger neighboring state's energy and mineral investments in the Russian Arctic and Far East through the creation of consortia whereby the much more substantial Indian investments serve as magnets to attract comparatively lesser ones from the rest of the region. If these investments eventually diversify into the commercial sector as planned, then those countries' companies could join relevant consortia along the VCMC in order to take advantage of this as well, building upon their successes jointly investing in Russia's natural resources. Paired with increasing Russian-Indian diplomatic coordination across the Indo-Pacific Rimland, as well as Russia's possible reciprocal investments in India and the other countries of South Asia following the aforementioned model whereby its EAEU partners could follow its lead in creating relevant consortia in order to establish a deeper presence in this part of the world, the overall effect could be a tightening of the Neo-NAM so long as there's the proper coordination and political will between its two anchor states.

\footnotetext{
${ }^{60}$ Our Western Friends Use Term 'Indo-Pacific' Instead of Asia-Pacific to Contain China - Lavrov. Sputnik. 15 Jan. 2020. URL: sputniknews.com/india/202001151078040582-our-western-friends-use-term-indo-pacific-instead-of-asia-pacific-tocontain-china---lavrov/ (accessed 20.03.2020)

${ }^{61}$ Joint Statement: Vision and Principles for the United States-India Comprehensive Global Strategic Partnership. The White House. 25 Feb. 2020. URL: www.whitehouse.gov/briefings-statements/joint-statement-vision-principles-unitedstates-india-comprehensive-global-strategic-partnership/ (accessed 20.03.2020)
} 
A complementary variation of this vision could be the gradual convergence of the Russian-led EAEU with the joint Indo-Japanese AAGC in Vietnam when considering that this ASEAN state already has a trade agreement with the former and is rapidly expanding relevant ties with the latter. In fact, Vietnam might become the centerpiece of the VCMC's eventual goal of bringing this scenario about, after which the experiences learned through this multilateral approach could be applied to other Southeast Asian states by the Neo-NAM's two leaders in the future. Vietnam is important not only for energy and commercial reasons, but also military ones too because it's previously expressed interest in the BrahMos supersonic cruise missiles that Russia and India jointly produced ${ }^{62}$. The unstated intent behind purchasing these weapons is to deter China's People's Liberation Army-Navy (PLAN) from making any military moves to enforce its so-called "nine-dash line" claim to the energy-rich South China Sea. As of the time of this article's submission for publication, there isn't any confirmation that Vietnam will officially buy the BrahMos, but Sputnik reported in December 2019 that the Philippines might become the first customer ${ }^{63}$. If Russia approves the sale of these state-of-the-art missiles to a country that's officially in a mutual defense alliance with the US in order to implicitly help its new customer defend their maritime claims from the PLAN, then it would follow that sales to its historical Vietnamese partner might naturally be forthcoming as well. Whether with the Philippines or more ideally (in the theoretical-strategic sense) with Vietnam, the importance of Russia and India coordinating the sale of their jointly produced weapons to third states lies in the possibility that it could eventually become a model that could be exported all throughout the other range of countries that they might jointly cooperate with along the Indo-Pacific Rimland, each case of which would carry with it the intent of improving the recipient state's capabilities to maintain their regional military balance so as to improve the odds of a political solution to their relevant disputes.

The third non-diplomatic opportunity that the Neo-NAM has after the aforementioned investment-commercial and military ones relates to the nuclear energy industry. Russia, India, and Bangladesh signed a tripartite pact for civil nuclear cooperation in 2018 that's being put to use to jointly construct the Roopur Nuclear Power Plant ${ }^{64}$. Upon completion, this project will represent a milestone in Russian-Indian cooperation and could prospectively be replicated in Africa. Russia's legacy of influence in the continent recently laid the basis for its return there through arms sales and diplomatic

\footnotetext{
62 India, Vietnam Hold Talks on Sale of Akash, Brahmos Missiles. The Economic Times. 12 July 2018. URL: www.economictimes. indiatimes.com/news/defence/india-vietnam-hold-talks-on-sale-of-akash-brahmos-missiles/articleshow/56959972. cms?from $=$ mdr (accessed 20.03.2020)

${ }^{63}$ Philippines Army Indicates Possible Induction Date for BrahMos Anti-Ship Cruise Missile. Sputnik. 6 Dec. 2019. URL: sputniknews.com/military/201912061077500792-philippines-army-indicates-possible-induction-date-for-brahmos-antiship-cruise-missile/ (accessed 20.03.2020

${ }^{64}$ Chaudhury, D.R. India, Russia, Bangladesh Sign Tripartite Pact for Civil Nuclear Cooperation. Economic Times. 1 Mar. 2018. URL: economictimes.indiatimes.com/news/defence/india-russia-bangladesh-sign-tripartite-pact-for-civil-nuclearcooperation/articleshow/63127669.cms?from $=\mathrm{mdr}$ (accessed 20.03.2020)
} 
outreaches which culminated in the Russia-Africa Summit in Sochi in October 2019. Speaking at the event, President Putin said that he hoped it would be able to lay a solid foundation for the future Russian-African cooperation for the next few years, while reaffirming the importance of expanding its scale in all areas, including politics, the economy, trade, culture and education, under the long-term partnership principle and while retaining the national sovereignty of African countries over their resources ${ }^{65}$. India is also expanding its influence in Africa as well, with the aim of integrating it into the nascent AAGC. Recalling their joint statement from September 2019 after the EEF that they plan to explore mutually acceptable and beneficial areas of cooperation in third countries, it would make sense for Russia and India to consider exporting their trilateral nuclear cooperation model with Bangladesh to all interested African states in order to jointly deepen their strategic presence in these countries with an aim towards tying them closer to the Neo-NAM.

Seeing as how the research has finally reached its end, its main results can be summarized as follows:

1. The ongoing global systemic transition has led to a present world order that is arguably bipolar instead of multipolar like it's commonly portrayed by Russian officials;

2. Russian-Indian relations form an axis of stability amidst these uncertain times and have the promising potential to become a dual pole of influence in their own right;

3. Russia is concerned about becoming overly dependent on China, hence the growing interest in teaming up with India to balance it and obtain as much strategic equality as possible through their joint efforts;

4. The recent proposal to establish a Neo-NAM, especially with a Russian-Indian core, is intriguing and deserves to be researched further;

5. The challenges inherent to this proposal mostly concern the US' pernicious influence in trying to keep Russia and India apart, as well as China's predictable suspicions about this network's strategic purpose;

6. The opportunities, however, are attractive enough to potentially inspire the two countries to continue cooperating with one another in this direction due to the envisioned mutual and multilateral benefits;

7. Nevertheless, any progress must proceed with caution after a careful assessment of the specific strategic situation surrounding each possible project in order to avoid any overreaction from the US and/or China.

The US is still by and far the most comprehensively influential actor in International Relations, though its power and influence have comparatively lessened since the turn of the century. It's debatable whether the current state of International Relations can be characterized as bipolar or multipolar, but in any case, it's clear that China is

${ }^{65}$ Russia - Africa Summit. President of Russia. 24 Oct. 2019. URL: en.kremlin.ru/events/president/news/61893 (accessed 20.03.2020) 
altogether the second most powerful and influential actor in the world. The global American-Chinese competition, whether described as representing bipolarity or as one of the main defining features of multipolarity, sets the strategic context in which the future of Russian-Indian relations will be practiced. This axis has recently strengthened as a result of the extremely positive outcome of Prime Minister Modi's participation in the September 2019 EEF and the unveiling of the VCMC. The decades-long trust that's been built between these two countries is now at the point where Russian experts are openly discussing the possibility of them jointly pooling their efforts to create a Neo-NAM for improving their positions in the ongoing global systemic transition, particularly vis-a-vis fellow BRICS and SCO member China.

The People's Republic is not officially regarded as a "threat", at least not by Russia (though some Indians have a different stance), but its economic asymmetry with both of those countries causes concern among their expert communities that their states might inevitably be relegated as its "junior partners" unless they proactively take the initiative to prevent this scenario from transpiring. One of the most pragmatic steps that could be undertaken is the joint creation of a Neo-NAM, the contours of which were elaborated upon in the research while the relevance of the concept itself pervaded throughout the text from the beginning until the end. This proposal is still in its earliest stages and might never even move beyond the academic realm, though it is nevertheless still interesting to discuss in order to compare its predicted strategic benefits and costs. On the one hand, the establishment of this network should in theory accelerate the transition to multipolarity or reinforce it if one believes that such a system is already in place (hence the reason why the US is so actively trying to court India away from the Neo-NAM), but on the other, it might inadvertently trigger a security dilemma with China that could worryingly reverse Eurasia's recent hard-earned integration gains.

\section{Conclusion}

The most important conclusion to be derived from the research is that more work must be done exploring the potentials and pitfalls of the proposed jointly led RussianIndian Neo-NAM. It might prospectively end up being the case that no such structure can realistically be created without the unnecessarily high risk of provoking an extremely negative reaction from the US and China. Should that be the case, then the back-up plan might be to informally conceptualize Russia and India's multilateral relations with third-party states through this framework in order to make comparatively smaller sized countries more attracted to working with them. Unofficially explaining the balancing benefits of trilateral (or larger) cooperation with these two, particularly the flexibility that it might eventually give them for better maneuvering between the US and China, might be all that's needed to seal the deal provided that India has the political will to resist American pressure to distance itself from Russia in this respect (which presently remains uncertain). In the event that this network successfully ex- 
pands to enough countries, then it could collectively become a critical mass that might then be more formally gathered together with time. Once again, any overt declarations of a Neo-NAM would have to be done very carefully to avoid offending the US and China, but there are still many informal ways to coordinate multilateral actions in the spirit of this concept so as to nevertheless make it a potentially invaluable international instrument in Russia and India's future diplomatic toolkits.

\title{
About the authors:
}

Andrew Korybko - Independent Researcher, PhD Degree Seeker, MGIMO University; Master Degree in International Relations (MGIMO University). 76, Prospect Vernadskogo, Moscow, Russia, 119454.

E-mail: korybko.e@my.mgimo.ru.

Vladimir M. Morozov - Candidate of History Associate Professor, Department of Diplomacy, MGIMO University, Vice-Rector for HR Policy. 76, Prospect Vernadskogo, Moscow, Russia, 119454.

E-mail: morozov@inno.mgimo.ru.

\section{Conflict of interests:}

The authors declare absence of conflict of interests.

\section{Сотрудничество России и Индии:} перспективы создания нового

\section{движения неприсоединения}

\author{
Э. Корыбко, В.М. Морозов \\ DOI 10.24833/2071-8160-2020-2-71-94-122
}

Московский государственный институт международных отношений (университет) МИД России

\begin{abstract}
Аннотация: В настоящее время продолжается трансформация системы международных отношений из прежней однополярности или, по мнению одних экспертов, к многополярности, или, в соответствии с менее популярной точкой зрения, к новой биполярности. При анализе современного мирового порядка становится ясно, что именно США и Китай являются глобальными лидерами, что ставит Россию и Индию - давних стратегических партнёров - в младшую позицию по отношению к ним, особенно к их общему соседу - КНР, с которой они разделяют членство в БРИКС и ШОС. Неореалистическая школа теории международных отношений опирается на исследование соотношения национальных интересов, которые могут совпадать: именно с учётом этого фактора у России и Индии рождается мотивация к совместному упрочнению своих стратегических позиции по отношению к Китаю, при этом избегая враждебного поведения, чтобы
\end{abstract}


не допустить риска непреднамеренного запуска «дилеммы безопасности» и сохранить достигнутые успехи в развитии евразийской интеграции.

В ключевых статьях, опубликованных дискуссионным клубом «Валдай» в 2019 г., шла дискуссия о возможности создания нового движения неприсоединения; в одной из них упор делается на возможное сотрудничество России и Индии, в соответствии с вышеупомянутыми структурными детерминантами, нацеленное на достижений этой стратегической цели. Такой тезис заслуживает дальнейшей проработки, что и стало задачей настоящего исследования: выявить возможности и ограничения сотрудничества России и Индии в деле создания нового движения неприсоединения, поместив данную экспертную инициативу в стратегический контекст глобальных системных трансформаций. Авторами было проанализировано около десятка статей и докладов российских экспертов, в результате чего был сделан вывод о том, что данная идея является обоснованной, но требует гораздо большего изучения проблем и возможностей реализации, чтобы стать чем-то большим, чем экспертное мнение.

Ключевые слова: Россия, Индия, Китай, многополярность, биполярность, новое движение неприсоединения, движение за мирное развитие, Южная Азия, Евразия

\section{Об авторах:}

Эндрю Корыбко - аспирант кафедры дипломатии, МГИМО МИД России. 119454, Россия, Москва, проспект Вернадского, 76. E-mail: korybko.e@my.mgimo.ru.

Владимир Михайлович Морозов - кандидат исторических наук, доцент кафедры дипломатии, проректор по кадровой политике, МГИМО МИД России. 119454, Россия, Москва, проспект Вернадского, 76. E-mail: morozov@inno.mgimo.ru.

\section{Конфликт интересов:}

Авторы заявляют об отсутствии конфликта интересов.

\section{References:}

Agius C., Karen D. 2011. 'Neutrality: A Really Dead Concept?' A Reprise. Cooperation and Conflict. 46(3). P. 265-284.

Entina E. 2014. Russia's Return to the International Arena. How the Eurasian Economic Union Should Be Estimated? Rivista Di Studi Politici Internazionali. 81(4/324). P. 527-544.

Jacobsen K.L., Troels G.E. 2017. The Global Political Context. Centre for Military Studies. P. 6-10.

Kabi D.B. 2002. Non-Aligned Movement and The New World Order. Proceedings of the Indian History Congress. Vol. 63. P. 1161-1169.

Kaushiki N., Hilal R. 2015. Sino-Russo Strategic Synergy in International Politics and Emerging Contours of South Asian Equilibrium: An Indian Perspective. Journal of International and Area Studies. 22(2). P. 1-18.

Lumumba-Kasongo T. 2015. Brazil, Russia, India, China, and South Africa (BRICS) and Africa: New Projected Developmental Paradigms. Africa Development / Afrique Et Développement. 40(3). P. 77-95.

Mishra M.K. 2016. Soft and Hard Power in India’s Foreign Policy. World Affairs: The Journal of International Issues. 20(2). P. 34-45.

Nafey A. 2005. IBSA Forum: The Rise of 'New' Non-Alignment. India Quarterly. 61(1). P. 1-79. 
Oosterveld W.T. et al. 2014. Why Are Pivot States So Pivotal? The Role Of Pivot States In Regional And Global Security. Edited by Tim Sweijs et al. Hague Centre for Strategic Studies. P. 97-137.

Ray A.K. 2012. Reinventing the Third World. Economic and Political Weekly. 47(11). P. 36-39.

Vieira M.A. 2013. IBSA at 10: South-South development assistance and the challenge to build international legitimacy in a changing global order. Strategic Analysis. 37(3). P. 291-298

Vieira M.A. 2016. Understanding Resilience in International Relations: The Non-Aligned Movement and Ontological Security. International Studies Review. 18(2). P. 290-311 